\title{
Tverrfaglige tiltak kan hjelpe tidligere kreftpasienter tilbake til arbeid
}

Stadig flere personer overlever etter en kreftdiagnose. Mange klarer seg svært bra selv om de kan ha langvarige problemer som utmattelse, smerter og depresjon. Disse problemene kan føre til problemer i arbeidslivet. Personer som har overlevd en kreftdiagnose har en 1,4 ganger større risiko for å være arbeidsledige enn andre. Individene selv, familier og samfunnet deler på denne byrden.

Hensikten med denne nye oversikten var å vurdere effekten av tiltak som skulle fremme det å komme tilbake i arbeid for kreftpasienter.

\section{HVA SIER FORSKNINGEN?}

Forfatterne fant studier som hadde vurdert følgende tiltak: psykologiske tiltak, tiltak som fremmer økt fysisk aktivitet, medikamentelle/medisinske tiltak og tverrfaglige tiltak.

Studiene var generelt av lav metodisk kvalitet, og de viste at:

- Tverrfaglige tiltak som involverte både psykologiske inter- vensjoner, veiledning, fysiske treningsprogrammer og yrkesveiledning førte til at flere kom tilbake til arbeid

- Psykologiske tiltak ikke hadde effekt på å returnere til arbeidslivet

- Fysisk treningsprogram førte ikke til at flere returnerte til arbeidslivet enn vanlig praksis

- Medikamentelle tiltak for å opprettholde funksjon ga samme resultat som mer radikale medisinske behandlinger

- Ingen av studiene fant at det var forskjell på livskvalitet mellom tiltaks- og kontrollgruppene

\section{HVA ER DENNE}

\section{INFORMAS JONEN BASERT PÅ?}

Forskere i Cochrane-samarbeidet har laget en ny oversikt over studier som har undersøkt effekten av tiltak som skulle fremme at personer som har overlevd kreftdiagnoser kommer tilbake til arbeidslivet. Forskerne gjorde systematiske søk i flere forskningsdatabaser, og fant 18 studier (14 randomiserte og fire kontrollerte) med til sammen 1652 deltakere som de inkluderte i oversikten. De var utført i USA $(\mathrm{n}=7)$, Sverige, Nederland, Frankrike og Tyskland. Hovedvekten av deltakerne hadde hatt brystkreft eller prostatakreft.

KILDE

de Boer AGEM, Taskila T, Tamminga SJ, Frings-Dresen MHW, Feuerstein $M$, Verbeek JH. Interventions to enhance return-to-work for cancer patients. Cochrane Database of Systematic Reviews 2011, Issue 2. Art. No.: CD007569. DOI: 10.1002/14651858. CD007569.pub2.

Skrevet av Liv Merete Reinar,

Nasjonalt kunnskapssenter for helsetjenesten 


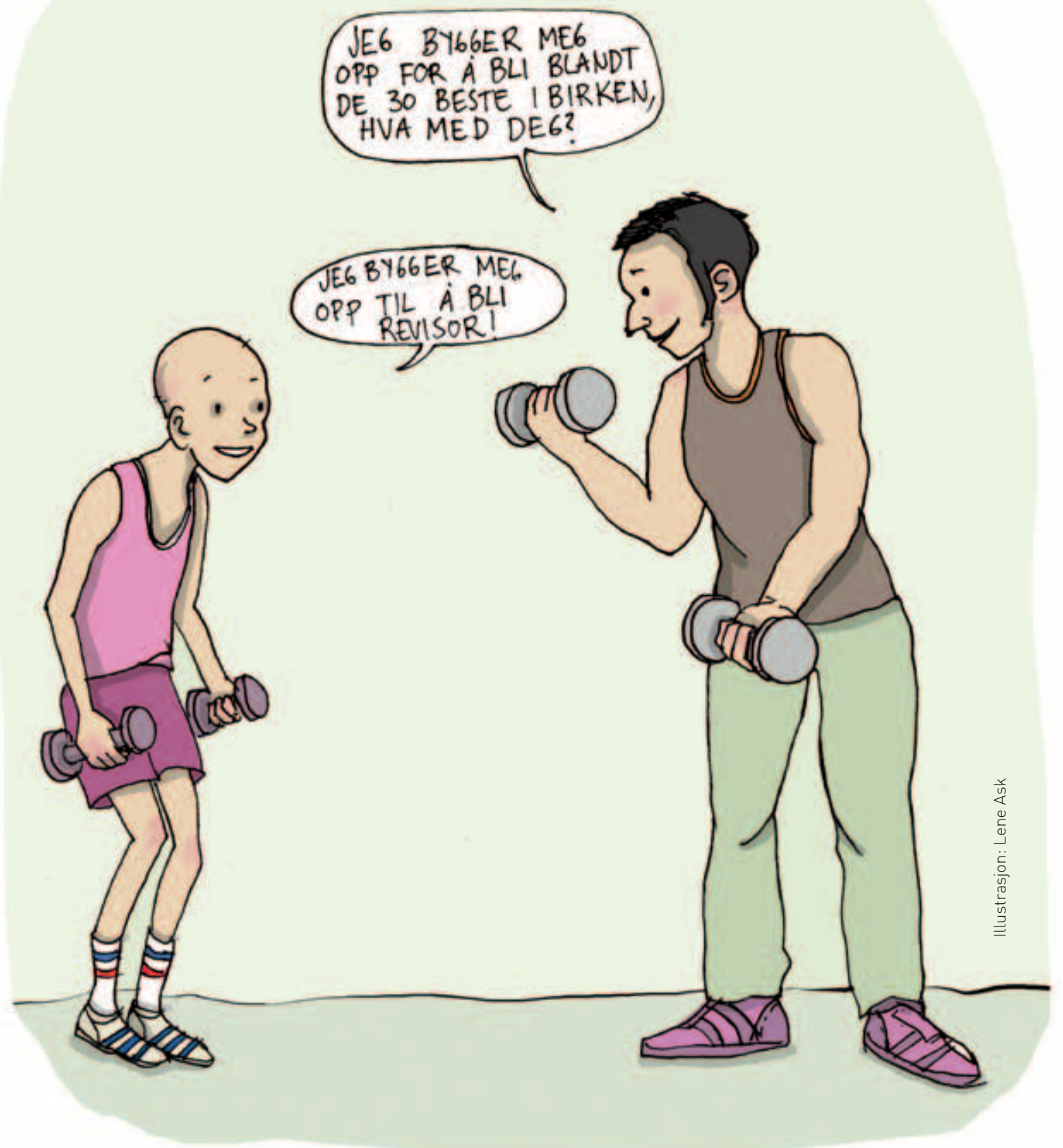

